\section{A) Check for updates}

Cite this: Inorg. Chem. Front., 2020, 7, 4320

\title{
Research progress on the inhibition of enzymes by polyoxometalates
}

\author{
Meijuan Zhao, $\dagger^{\mathrm{a}}$ Xiangsong Chen, $\grave{\dagger}^{\mathrm{a}}$ Guoxiang Chi, ${ }^{\mathrm{a}}$ Die Shuai, ${ }^{a} \mathrm{Li}$ Wang, (D) *a \\ Bingnian Chen*b and Jian Li*a
}

Polyoxometalates (POMs) are a kind of inorganic cluster metal complex with various biological activities, such as anti-Alzheimer's disease, antibacterial, anti-cancer, anti-diabetes, anti-virus, and so on. The mechanism of their action at the molecular level is basically unknown. However, some studies have shown that the inhibitory effect of POMs on several enzyme families (such as $\alpha$-glucosidase, tyrosinase, protein kinase or exonuclease) may be related to the pharmacological properties of POMs. In addition, POMs also inhibited sialyltransferase, thiotransferase, deacetylase and virus reverse enzyme to different degrees. Combining the results of research groups, it was found the structure and composition of POMs may indirectly affect their inhibition ability. Therefore, this paper reviews the inhibitory effects of POMs on various enzymes in order to contribute to the application of polyoxometalates in biomedicine.

Received 16th July 2020,

Accepted 9th September 2020

DOI: 10.1039/d0qi00860e

rsc.li/frontiers-inorganic

\section{Introduction}

Polyoxometalates are unique metal oxygen clusters, which are usually formed by the condensation of oxygen and early transition metals. ${ }^{1}$ The number and substitution position of POM transition metal ligands determine its ever-changing structure and a wide range of properties. These molecules are composed of oxygen bridged early transition metals with their highest oxidation states (e.g., Mo, $\mathrm{W}$, and $\mathrm{V})$. They are a combination of polyhedrons based on a common angle and common edge. In a broad sense, they can be divided into isopolyanions and heteropolyanions. Compared with isopolyanions, heteropolyanions have a more stable structure and better diversity, so they are also a focus of research. ${ }^{2}$ Their beautiful and rich cage structure has resulted in several centuries of research and attracted attention in the chemical field. POMs have the characteristics of nanometer size, stable structure, high charge and excellent optical, electrical and magnetic properties. Because of their good redox and photooxidation properties, polyoxometalates are widely used in the field of catalysis. Polyoxometalates are green catalysts, which have a role in various fields. When they are used in combination with other components, they can be used as a new multi-functional catalyst and improve the catalytic efficiency. ${ }^{3-5}$ In view of the unique magnetic properties of polyoxometalates, Brønsted

\footnotetext{
${ }^{a}$ College of Food and Biological Engineering, Jimei University, Xiamen, 361021, P.R. China.E-mail: wanglimerry@jmu.edu.cn, 49739792@qq.com

${ }^{b}$ Xiamen University Hospital, Xiamen, 361005, P.R. China.

E-mail:3421836578@qq.com

$\dagger$ These authors contributed equally to this work
}

acidity and other characteristics, polyoxometalates play an important role in solving environmental problems, such as toxic gas isolation, wastewater purification, etc. ${ }^{6}$ Polyoxometalates can also be used in multifunctional composite materials such as nanomaterials. ${ }^{7}$

Due to their special structure and excellent physical and chemical properties, POMs are not only widely used in the fields of industrial catalysis and functional materials, but also biomedicine. As one of the few inorganic drugs with high efficiency and low toxicity, POMs have attracted wide attention in the field of biomedicine. According to the literature, POMs have the characteristics of being antibacterial, ${ }^{8}$ anti-virus, ${ }^{2}$ anti-cancer $^{9}$ and so on. It was found that polyisotungstate combined with $\beta$-lactam antibiotics could enhance the efficacy of antibiotics against drug-resistant strains. ${ }^{7}$ Wang et al. ${ }^{10}$ synthesized a series of novel pyridines $\left(\mathrm{A}_{7} \mathrm{Pti}_{2} \mathrm{~W}_{10} \mathrm{O}_{40}\right)$ by using PM-19 $\left(\mathrm{K}_{7} \mathrm{PTi}_{2} \mathrm{~W}_{10} \mathrm{~W}_{40}\right)$ as the lead compound. The single cycle pseudovirus infection test showed that the designed polyoxometalate pyridine had low toxicity to TZM BL cells and high inhibitory activity against HIV-1 virus. Dong et al. ${ }^{11}$ screened five novel histone deacetylase inhibitors (HDACls), by using the cell screening system targeting the p21 gene promoter. Among them, PAC-320 has a strong inhibitory effect on intracellular HDAC activity and has obvious inhibitory effect on the growth of many kinds of tumor cells. The typical characteristics of polyoxometals such as structure, size and special surface group complex enzyme molecules are very suitable for specific interactions in biological systems. ${ }^{12}$ Chi et al. found that POMs with a Keggin type and vanadium substituted Dawson type structure are the most effective and competitive inhibitors of $\alpha$-glucosidase and have great clinical value in the 
development of drugs for the treatment of non-insulin dependent diabetes mellitus (NIDDM). Our experimental team synthesized and characterized two kinds of phosphomolybdates, and studied the inhibitory effect of two kinds of POMs on tyrosinase. The results showed that both POMs could effectively prevent the formation of melanin, which opened up a direction for the development of POMs in the field of food preservation and decolorization. ${ }^{13,14}$ In addition to the above-mentioned enzymes, polyoxometalates also inhibited the activities of nucleotidase, phosphatase, sulfate transferase, sialyltransferase, histone acetylase, nuclease and protease to varying degrees. The purpose of this paper is to review the inhibitory effects of polyoxometalates on various enzymes and to provide some ideas for the development of enzyme inhibitors in the field of biomedicine.

\section{Inhibition of enzymes by polyoxometalates}

Although polyoxometalates have a variety of biological activities because of their special structure and there is a considerable amount of literature about POMs regarding their antiAlzheimer's disease, anti-cancer, anti-virus, antibacterial, antidiabetes characteristics and so on, due to the structural variability of polyoxometalates, it is difficult for scientists to study their biological activities at the molecular level in most cases. The action mechanism of POMs at the molecular level is completely unknown. Due to the following reasons, there are some difficulties in elucidating the enzyme inhibitory activity of POMs: ${ }^{12}$ (1) in most studies, the POM compounds studied are very limited, but the POM structures are changeable, which reduces the universality of the study; (2) the stability of POMs is different, and the stability of the synthesized compounds may be lower than that of the intermediate fragments; (3) whether the inhibition of POMs on enzymes is a competitive mechanism remains to be confirmed.

It has been reported that the biological activity of polyoxometalates is closely related to the interaction of related enzymes. Bijelic et al. ${ }^{15,16}$ have reported that covalent and noncovalent interactions (such as hydrogen bonds, electrostatic interactions, etc.) can occur between polyoxometalates and proteins, which explained the interaction between polymetallic hydrochloride and protease at the molecular structure level. This research provided basis and direction for explaining the interaction between protease and POMs. Therefore, in the following article, we will explain and speculate the mechanism of action at the molecular level by analyzing the experiments on polyoxometalates carried out by researchers in various fields. We hope that our work can provide some ideas for the application of polyoxometalates in this field.

\section{$\alpha$-Glucosidase}

With the passing of time, the change in people's life style and the improvement in nutrition levels, being sedentary has become a common living habit. A chronic metabolic disease quietly enters people's lives, which is diabetes. Diabetes is due to metabolic disorders, related to abnormal elevated blood glucose levels, mainly caused by insufficient insulin secretion or insulin resistance of cells in the body, or both. ${ }^{17}$ Diabetes is mainly divided into two types: ${ }^{18}$ type 1 or immune diabetes, also known as insulin dependent or juvenile diabetes. The destruction of islet B cells is mediated by autoimmunity, resulting in an absolute lack of insulin, accounting for only $5 \%$ of cases. The other is type 2 or diabetes, also known as non-insulin dependent or adult diabetes. The second type of diabetes is acquired due to the progressive defect of insulin secretion caused by the resistance of cells in the body to insulin. This type of diabetes accounts for the vast majority of cases, about $90 \%$ of $\mathrm{Mel} 95 \%$. Diabetes itself is not scary, but the resulting complications can seriously affect your health. Long-term effects can lead to retinopathy, renal failure, foot ulcers, amputation, cardio-cerebrovascular diseases and so on. ${ }^{19}$ With the rising incidence of diabetes in the world, diabetes has become the focus of scientists' research.

The treatment for diabetes mainly focuses on two aspects: source and pathway, in other words, controlling glucose intake or interfering with glucose transport. Among them, inhibiting the activity of $\alpha$-glucosidase is a practical and effective method. $\alpha$-glucosidase is a membrane-binding enzyme in small intestinal epithelial cells, ${ }^{20}$ which is responsible for converting a glycosidic bond into oligosaccharides and finally into monosaccharides, ${ }^{21}$ which participates in the digestion and absorption of carbohydrates such as starch and sucrose. $\alpha$-glucosidase is a key enzyme that affects human metabolism, so $\alpha$-glucosidase is considered to be an important target for the treatment of non-insulin dependent diabetes. ${ }^{22}$ By inhibiting the activity of $\alpha$-glucosidase, the absorption and release of carbohydrates in the intestine slow down and the level of postprandial blood glucose is reduced. ${ }^{23}$

Most researchers at home and abroad prepare $\alpha$-glucosidase inhibitors by extracting natural active components from plants or synthesizing phenolic hydroxyl derivatives. However, few studies have paid attention to the components that inhibit $\alpha$-glucosidase in inorganic substances. ${ }^{24}$ $\alpha$-Glucosidase inhibitors widely used in clinic, such as acarbose, misoglitol, and voglibose are all derived from natural products. $^{25}$ However, these commonly used clinical $\alpha$-glucosidase inhibitors have high cost and cause serious side effects on the gastrointestinal tract, ${ }^{20}$ which limit their application. Therefore, the design of cheap, safe and efficient enzyme inhibitors has become the focus of research.POMs has many biological activities due to their unique structural and functional properties, including the inhibition of $\alpha$-glucosidase. Dinčić et $a .^{18}$ used Wistar rats as a model system to evaluate the in vivo toxicity of two polyoxotungstates $\left(\left(\mathrm{NH}_{4}\right)_{14}\left[\mathrm{Na} @ \mathrm{P}_{5} \mathrm{~W}_{30} \mathrm{O}_{110}\right] \cdot 31 \mathrm{H}_{2} \mathrm{O} \quad\left\{\mathrm{NaP}_{5} \mathrm{~W}_{30}\right\}\right.$, $\left.\mathrm{K}_{14}\left[\mathrm{Ag} @ \mathrm{P}_{5} \mathrm{~W}_{30} \mathrm{O}_{110}\right] \cdot 22 \mathrm{H}_{2} \mathrm{O} \cdot 6 \mathrm{KCl}\left\{\mathrm{Ag}_{5} \mathrm{P}_{30}\right\}\right)$ with potential anti-diabetic activity. The results show that both substances have hypoglycemic effects in rats, but there is certain toxicity (mild liver toxicity, nephrotoxicity). This research group has been focusing on polyoxometalates for a long time. At the 
present stage, we mainly studied the two structures of Keggin type and Dawson type. At present, the research group has obtained preliminary results in the study of the inhibitory effect of polyoxometalates on $\alpha$-glucosidase. Chi et al. ${ }^{22,23}$ have found that Keggin type POMs, which is replaced by transition metal, and vanadium substituted Dawson type POMs are effective and competitive inhibitors of $\alpha$-glucosidase. In addition, they have micro-molar inhibitory effect on $\alpha$-glucosidase. We used enzyme kinetic experiments to study its inhibitory mechanism; the results showed that both structures of the POMs showed a significant inhibitory effect, and both were reversible. Taking heteroatoms to replace different polyoxometalates $\mathrm{GaMo}_{12}, \mathrm{SiMo}_{12}, \mathrm{PMo}_{12}$ as an example, the results of the enzyme kinetics experiment are shown in Fig. 1. It can be seen from the figure that several straight lines are formed between the remaining enzyme activity and the concentration of the enzyme added to the reaction system, and these straight lines all pass through the origin. Therefore, $\mathrm{GaMo}_{12}, \quad \mathrm{SiMo}_{12}, \quad \mathrm{PMo}_{12}$ are reversible inhibitions of $\alpha$-glucosidase. It can be seen that the polyoxometalates of the two structures and the enzyme are connected by non-covalent bonds. Then, we used molecular docking simulations to further illustrate the interaction between polyoxometalates and enzymes. In the result, POMs binds to the enzyme active site through van der Waals force and hydrogen bonding. The synthesized compounds $\mathrm{PMo}_{12}\left(\mathrm{IC}_{50}=6.41 \pm 0.38 \mu \mathrm{M}\right), \mathrm{PMo}_{11} \mathrm{Ni}$ $\left(\mathrm{IC}_{50}=37.29 \pm 1.72 \mu \mathrm{M}\right)$ and $\mathrm{P}_{2} \mathrm{Mo}_{15} \mathrm{~V}_{3}\left(\mathrm{IC}_{50}=57.01 \pm 2.11 \mu \mathrm{M}\right)$ had the strongest inhibitory effect on $\alpha$-glucosidase, which was about 117, 20 and 13 times that of acarbose $\left(\mathrm{IC}_{50}=64.31 \pm\right.$ $1.47 \mathrm{mM}$ ), which is the standard compound currently available for alpha-glucosidase inhibitors. From the study of three factors affecting the structure of POMs: the kind of heteroatoms, the number of transition metal substitution and the number of vanadium substitution, it was found that the inhibitory effects of different factors on $\alpha$-glucosidase were slightly different. Hence, the structure and composition of POMs may affect their redox, acidity and electrostatic effects. In addition, the charge of the central atom has a significant indirect effect on the inhibition behavior of POMs. ${ }^{22,23} \mathrm{Hu}$ et al. ${ }^{1,24}$ investigated the inhibitory effects of Dawson-type transition metal-substituted polyoxometalates and Keggin-type vanadium-substituted polyoxometalates on $\alpha$-glucosidase. They also used enzyme kinetic experiments to determine the mechanism of inhibition, and used molecular docking simulations to further explain the interaction between polyoxometalates and enzyme molecules. The results show that two different types of polyoxometalates have inhibitory effects on $\alpha$-glucosidase and both are reversible inhibition, which is better than the current standard of $\alpha$-glucosidase inhibitors, acarbose. The synthesized compounds $\mathrm{P}_{2} \mathrm{Mo}_{18}\left(\mathrm{IC}_{50}=0.174 \pm\right.$ $0.0146 \mu \mathrm{M}), \mathrm{P}_{2} \mathrm{Mo}_{17} \mathrm{Cu}\left(\mathrm{IC}_{50}=40.13 \pm 0.61 \mu \mathrm{M}\right)$ and $\mathrm{PMo}_{9} \mathrm{~V}_{3}$ $\left(\mathrm{IC}_{50}=9.63 \pm 0.43 \mu \mathrm{M}\right)$ had the strongest inhibitory effect on $\alpha$-glucosidase, and inhibition efficiency of Dawson matrix is higher than that of transition metal substituted polyoxometa-
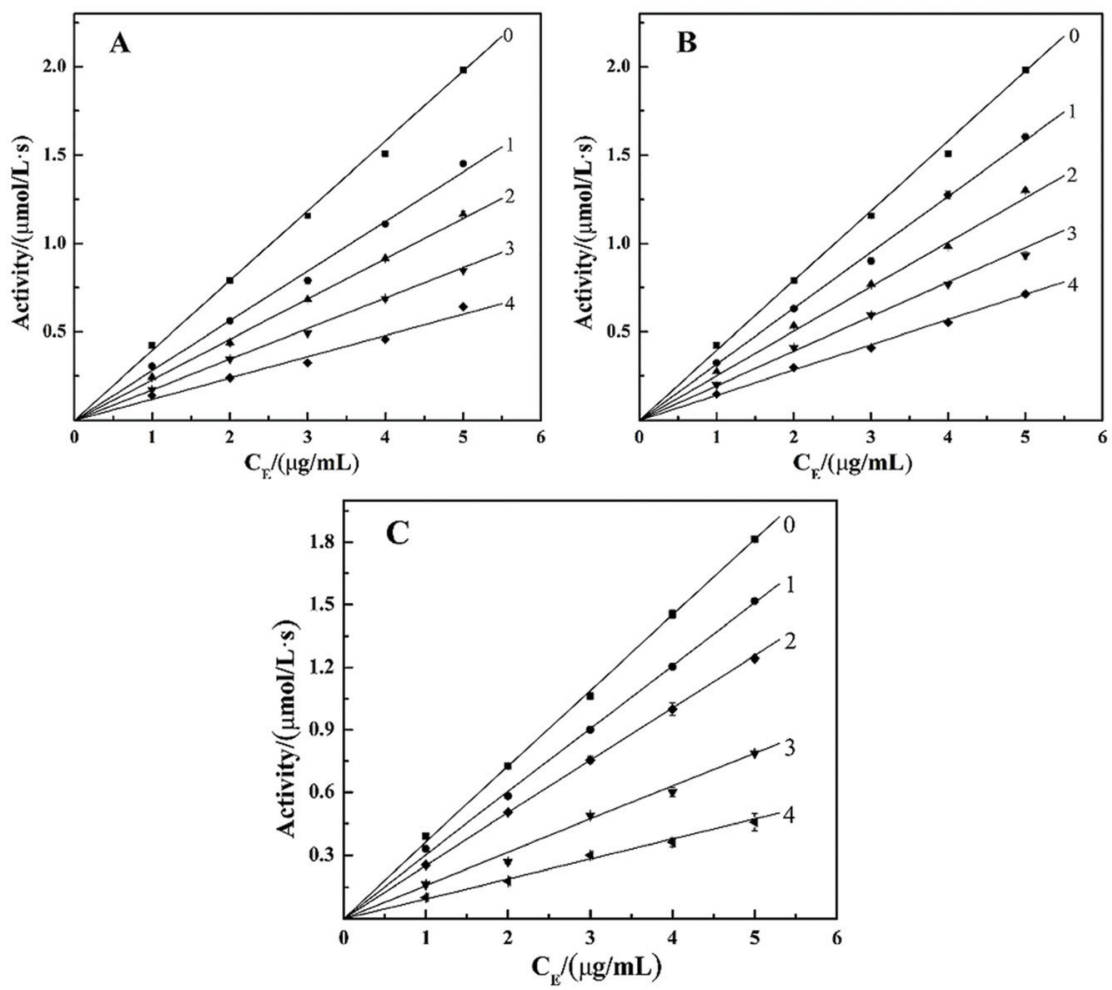

Fig. 1 Inhibitory mechanism of compounds $\mathrm{GaMo}_{12}$ (A), $\mathrm{SiMo}_{12}$ (B) and $\mathrm{PMo}_{12}$ (C) on the activity of $\alpha$-glucosidase. The concentrations of GaMo 12 for curves $0-4$ of (A) were $0,0.3,0.4,0.5$ and $0.75 \mathrm{mM}$, respectively. The concentrations of $\mathrm{SiMo}_{12}$ for curves $0-4$ of (B) were $0,0.015,0.025,0.028$ and $0.045 \mathrm{mM}$, respectively. The concentrations of $\mathrm{PMo}_{12}$ for curves $0-4$ of $(\mathrm{C})$ were $0,0.01,0.02,0.025$ and $0.03 \mathrm{mM}$, respectively. 
lates. Molecular docking simulations show that it also exist hydrogen bonds and van der Waals forces between polyoxometalates with two different structures and $\alpha$-glucosidase.

In summary, the research group studied the inhibitory effect of two structures of polyoxometalates on $\alpha$-glucosidase, and compared the effects of three different factors: the type of heteroatoms, transition metal elements, and the number of transition metal substitution. The results show that the biological activity of polyoxometalates depends on various factors, such as charge distribution, acidity, metal ions, etc. The inhibitory effect of polyoxometalates on enzymes mainly depends on their redox properties. By comparing molybdic acids substituted with different heteroatoms, it was found that the oxidizability of polyoxometalates is affected by the electrostatic effect of the anion charge number. As the charge number of heteropolyanions (Ga: -3 , Si: $-4, \mathrm{P}:-5$ ) increases, the oxidizability of polyoxometalates decreases and the inhibitory effect increases significantly(Fig. 2). Molecular docking clearly shows the interaction between the ligand and the active site of the $\alpha$-glucosidase receptor. The docking scores of $\mathrm{GaMo}_{12}, \mathrm{SiMo}_{12}$ and $\mathrm{PMo}_{12}$ are respectively $-11.68 \mathrm{kcal} / \mathrm{mol},-13.62 \mathrm{kcal} \mathrm{mol}^{-1}$ and $-14.80 \mathrm{kcal} \mathrm{mol}^{-1}$. These scores mean that the docking of these three compounds with $\alpha$-glucosidase is successful (generally, the docking score is $<-7 \mathrm{kcal} \mathrm{mol}^{-1}$ ), and the smaller the docking score value, the better the compound's ability to bind to biological macromolecules. Therefore, the inhibitory effect of the three compounds is $\mathrm{GaMo}_{12}<\mathrm{SiMo}_{12}<\mathrm{PMo}_{12}$. As shown in Fig. 3, the three compounds formed hydrogen bonds and van der Waals interactions in the active center. $\mathrm{PMo}_{12}$ produces 7 hydrogen bonds with amino acid residues Tyr158, Ser240, Asp242, His280, Ser311 and Arg315 in the active region (Fig. 3A), while $\mathrm{SiMo}_{12}$ produces 5 hydrogen bonds with surrounding amino acid residues Ser240, His280, Pro312 and Arg315 Hydrogen bonding (Fig. 3B), and $\mathrm{GaMo}_{12}$ produces only three hydrogen bonds with surrounding amino acid resi-

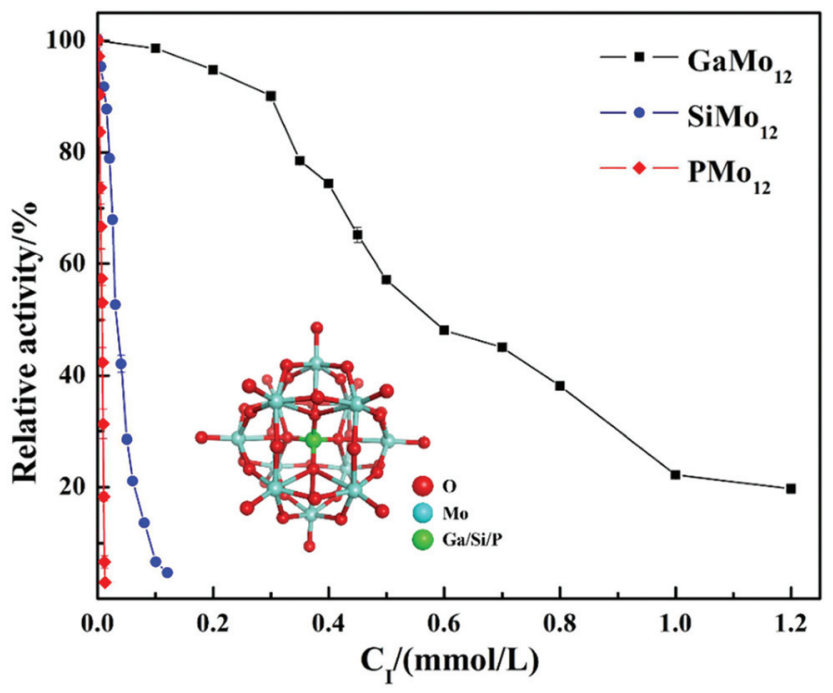

Fig. 2 Inhibitory effect of compounds $\mathrm{GaMo}_{12}, \mathrm{SiMO}_{12}$ and $\mathrm{PMO}_{12}$ on the activity of $\alpha$-glucosidase. dues Ser240 and Asp242 (Fig. 3C). However, there is no significant difference in the number of amino acid residues that form the van der Waals interaction. It shows that hydrogen bonding is the main driving force for the different inhibition effects of the three compounds. The change in heteroatoms reduced the stability of the combination between enzymes and polyoxometalates, which in turn affects the inhibitory effect on the enzyme. ${ }^{22,23}$ When the central atom is fixed, the oxidizability of the heteropolyanion changes with the coordination atom, and vanadium is easier to reduce than molybdenum. When the coordination atom Mo is replaced by the low-valent metal ion $\mathrm{V}^{5+}$, the negative charge of the heteropolyanion increases and the acid strength tends to decrease. Hence, as the number of vanadium substitutions increases, the oxidizing power of polyoxometalates increases, thereby changing the inhibitory effect on the enzyme. But excessive vanadium substitution will reduce the inhibitory effect on the enzyme (Fig. 4). ${ }^{22}$ The substitution of different transition metal elements changed the structure of the polyoxometalates, affecting their redox properties and ultimately affecting the inhibition of the enzyme.

In the future, the subsequent studies on the modification of POMs to improve their inhibitory ability can be adjusted with reference to these influencing factors. Besides, some studies have shown that tungstate can stimulate the functional regeneration of islet B cells in animals, can prevent ALR1 and ALR2-mediated polyol pathway and related AGEs, can effectively reduce blood glucose levels in vivo and in vitro, and prevent related complications. ${ }^{21}$ Dinčić et al. ${ }^{18}$ studied the hepatotoxicity and nephrotoxicity induced by POMs in mice for two weeks, and the results showed that the effect was mild.

Many studies have shown that polyoxometalates are new, efficient, low-toxic and cheap $\alpha$-glucosidase inhibitors. Compared with the organic drugs widely used in clinic, the unparalleled advantages of polyoxometalates have established their position in the field of biomedicine in the future. They have great potential and a broad market for the development of diabetes drugs.

\section{Tyrosinase}

Melanin is a kind of biopolymer spread all over the world of animals and plants, and the research on the regulation of melanin biosynthesis has been carried out for hundreds of years. The chemical reactions involved were determined as early as the 1920s. ${ }^{26}$ Melanin, a pigment that determines the color of human skin, eyes and hair, is secreted by melanocytes distributed in the basal layer of the dermis. ${ }^{27}$ Under normal circumstances, it can protect the skin by absorbing ultraviolet sunlight and scavenging reactive oxygen species, and plays a very important role in camouflage and imitation of animals in nature. ${ }^{28}$ However, excessive pigment accumulation in some parts will cause skin problems such as chloasma, senile spots and freckles, and some intermediate products of melanin synthesis are also closely related to some diseases. The type and quantity of melanin synthesized by melanocytes and its distribution in the surrounding keratinocytes determine the actual 

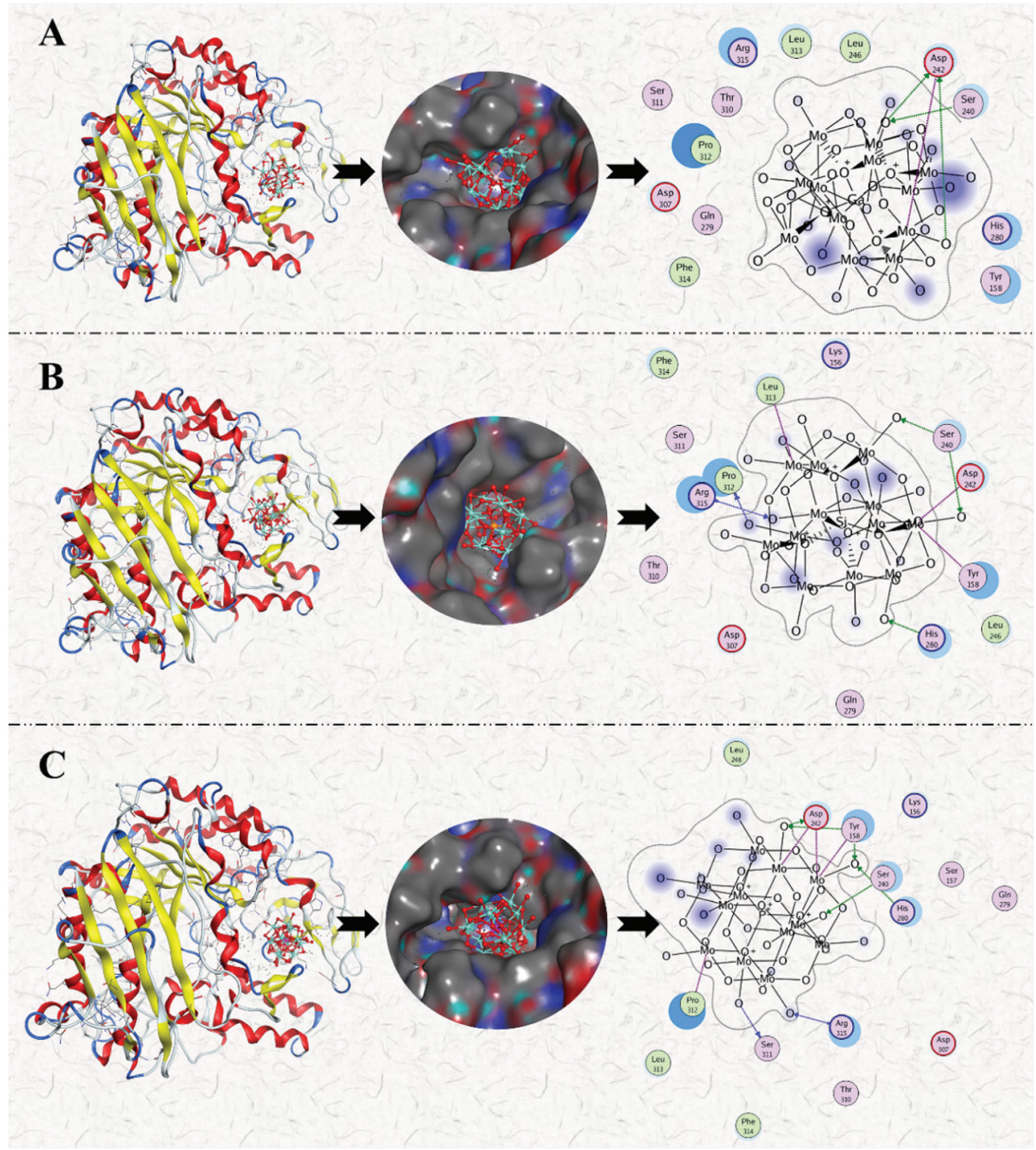

Fig. 3 Binding mode of the ligand $\mathrm{GaMO}_{12}(\mathrm{~A}), \mathrm{SiMO}_{12}$ (B) and $\mathrm{PMO}_{12}$ (C) docked into the binding site of $\alpha$-glucosidase.

color of the skin. The browning of fruits and vegetables will affect their sensory quality and shorten the shelf life of goods, so effectively preventing food browning is an issue of great concern to the food industry. The rate of enzymatic browning mainly depends on the content of enzymes and phenols in the tissues, which will react with each other to produce darker pigments on the surface of fruits due to tissue damage. ${ }^{29}$ Both excessive accumulation of melanin in the human body and browning of fruits and vegetables involve a key enzyme, tyrosinase.

Tyrosinase (EC1.14.18.1) is a kind of copper containing multifunctional oxidase widely distributed in animals and plants, ${ }^{30}$ which relies on copper ions to exert its physiological activity. ${ }^{31}$ Also known as polyphenol oxidase (PPO), it is widely found in animals, plants and microorganisms. It catalyzes three reactions of melanin synthesis: tyrosine hydroxylation to 3pyr4-dihydroxyphenylalanine (DOPA), DOPA oxidation to dopaquinone and 5. 6-Dihydroxyindole conversion to melanin. ${ }^{32}$ The formation of melanin is initiated by the oxidation of L-tyrosine to dopaquinone (DQ) by the key enzyme tyrosinase (TYR). The resulting quinone will be used as the substrate for the synthesis of melanin. The formation of DQ is a rate-limiting step in melanin synthesis, because other processes of the reaction can take place spontaneously at the physiological $\mathrm{pH}$ value. ${ }^{33}$ Therefore, although tyrosinase, tyrosinase-related protein-1 (TRP-1) and tryptophan-associated protein-2 (TRP-2) play an important role in melanin synthesis, ${ }^{33}$ tyrosinase is the only necessary enzyme for melanin synthesis. Therefore, down-regulation of tyrosinase has become the most important way to develop melanin synthesis inhibitors. In fact, tyrosinase is the most studied target to inhibit melanin production, and it has been widely used to improve a series of skin problems caused by melanin deposition in the pharmaceutical and cosmetic industry. ${ }^{34}$ There are many ways to prevent enzymatic browning by controlling melanin production. Generally speaking, enzymatic browning 


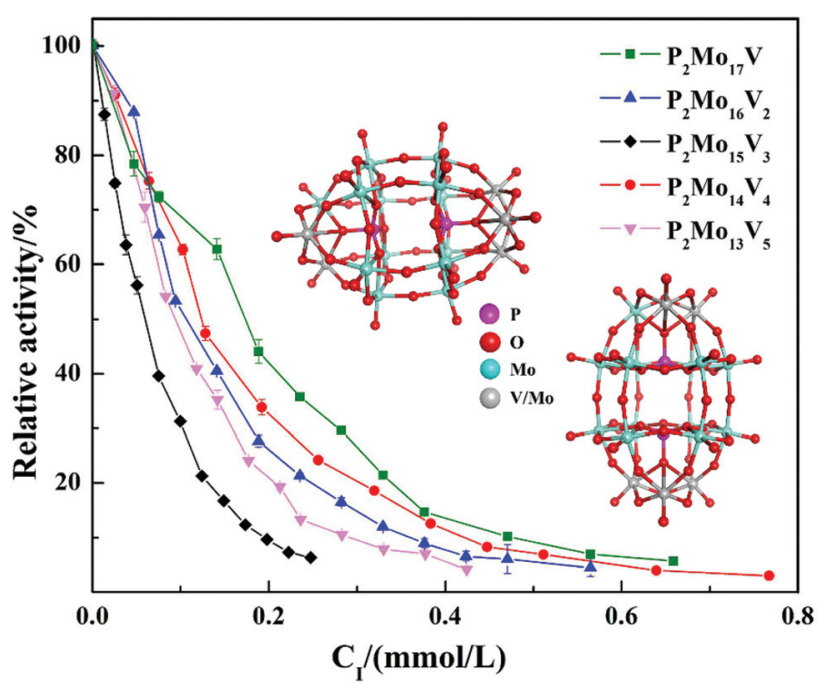

Fig. 4 Inhibitory effect of five vanadium-substituted Dawson-type polyoxometalates on $\alpha$-glucosidase.

can be prevented by: ${ }^{35}$ (a) selecting varieties with low PPO and/ or phenolic concentrations; (b) using appropriate processing procedures, which can inhibit melanin synthesis without significant impact on product safety. The former is regulated in the field of molecular biology and biotechnology, while the latter can be achieved by inhibiting PPO. The inhibition of PPO can obviously be achieved by thermal inactivation, which is usually irreversible, but inevitably leads to significant sensory changes. Therefore, it is a good choice to look for natural or synthetic tyrosinase inhibitors to inhibit tyrosinase activity. There are few clinical studies on many tyrosinase inhibitors. The most typical commercial tyrosinase inhibitors are Kojic acid and arbutin, but they have potential toxicity to cell and cause dermal sensitization at therapeutic concentrations. ${ }^{36}$ Because the extraction process from natural substances is complicated and the extraction rate is low, the synthetic compounds are simple and fast to operate and the yield is high. POMs have the characteristics of structural diversity, adjustable charge variability, high stability, non-toxicity, nonvolatility and strong electron acceptance, it is possible for site recognition, molecular recognition, molecular interaction and so on. The study of POMs inhibition on the activity of various enzymes has become a hot spot in the research of POMs properties and the development of safe, non-toxic and efficient enzyme inhibitors in recent years. In our laboratory, we used polyoxometalates as the main body to study the inhibitory effect of polyoxometalates with different types and structures on tyrosinase. Xing et al. ${ }^{14}$ synthesized and characterized Keggin type copper substituted phosphomolybdic acid $\left(\mathrm{Na}_{7} \mathrm{PMo}_{11} \mathrm{CuO}_{40}\right.$, referred to as $\left.\mathrm{PMo}_{11} \mathrm{Cu}\right)$. The inhibitory effect of $\mathrm{PMo}_{11} \mathrm{Cu}$ on tyrosinase and melanogenesis in B16 melanoma cells was studied. The results showed that $\mathrm{PMo}_{11} \mathrm{Cu}$ had a strong inhibitory effect on tyrosinase activity and was a reversible and competitive inhibitor. The $\mathrm{IC}_{50}$ value was estimated to be $0.480 \pm 0.003 \mathrm{mM}$. $\mathrm{PMo}_{11} \mathrm{Cu}$ inhibited cell viability, tyrosinase activity and melanogenesis of B16 melanoma cells treated with $0-200 \mu \mathrm{M}$ for 24 hours. Xing et al. ${ }^{13}$ also synthesized Keggin-type iron-substituted phosphomolybdic acid $\left(\mathrm{Na}_{6} \mathrm{PMo}_{11} \mathrm{FeO}_{40}\right.$, abbreviated as $\left.\mathrm{PMo}_{11} \mathrm{Fe}\right)$ and studied its inhibitory effect on tyrosinase. The results indicated that the compound exhibits reversible and non-competitive inhibition. The $\mathrm{IC}_{50}$ value was estimated to be $0.461 \pm$ $0.004 \mathrm{mM}$. Chen et al. $^{37}$ synthesized and characterized $\alpha-\mathrm{Na}_{8} \mathrm{SiW}_{11} \mathrm{CoO}_{40}$, and studied the inhibitory effect of $\alpha-\mathrm{Na}_{8} \mathrm{SiW}_{11} \mathrm{CoO}_{40}$ on the activity of mushroom tyrosinase. Then, they studied the effects of a-Na $\mathrm{SiW}_{11} \mathrm{CoO}_{40}$ on the browning of fresh-cut apples. The results showed that $\alpha-\mathrm{Na}_{8} \mathrm{SiW}_{11} \mathrm{CoO}_{40}$ had obvious inhibitory effect on tyrosinase. Kinetic analysis showed that $\alpha-\mathrm{Na}_{8} \mathrm{SiW}_{11} \mathrm{CoO}_{40}$ was an irreversible competitive inhibitor. The $\mathrm{IC}_{50}$ value is approximately $0.239 \mathrm{mM}$. In addition, $\alpha-\mathrm{Na}_{8} \mathrm{SiW}_{11} \mathrm{CoO}_{40}$ could significantly reduce the browning process of apple slices, inhibit the activity of polyphenol oxidase (PPO), increase the activity of peroxidase, and promote the production of phenolic compounds and ascorbic acid. Xing et al..$^{38}$ synthesized two polyoxometalates containing glycine, ( $\mathrm{HGly})_{3} \mathrm{PW}_{12} \mathrm{O}_{40}$ and $(\mathrm{HGly})_{4} \mathrm{SiW}_{12} \mathrm{O}_{40}$, and evaluated the effect of POMs on tyrosinase. They found that both POMs can significantly inhibit tyrosinase, which are reversible inhibitions. Their half-inhibition concentration values were estimated to be 1.55 and $1.39 \mathrm{mM}$, respectively. $\mathrm{Hu}$ et al. ${ }^{39}$ synthesized Dawson-type phosphotungstic polyoxometalate $\alpha / \beta-\mathrm{K}_{6} \mathrm{P}_{2} \mathrm{~W}_{18} \mathrm{O}_{62} \cdot 10 \mathrm{H}_{2} \mathrm{O}$ (abbreviated as $\mathrm{P}_{2} \mathrm{~W}_{18}$ ), and studied the effect of $\mathrm{P}_{2} \mathrm{~W}_{18}$ on mushroom tyrosinase. It can act as an irreversible inhibitor on tyrosinase. The $\mathrm{IC}_{50}$ value was estimated to be $0.05 \mathrm{mM}$ for monophenolase and $0.64 \mathrm{mM}$ for diphenolase. It was also found through experiments that the compound can inhibit the growth of E. coli, Bacillus subtilis, and yeast. In addition, there are many polyoxometalates available as potential tyrosinase inhibitors.

Our research group mainly studied phosphomolybdates with two structures of Keggin and Dawson. Table 1 summarizes the relevant research results of the research group. In addition, Breibeck et al. ${ }^{40}$ studied the inhibitory effects of a series of structurally related polyoxotungstates (POTs) of the $\alpha$-Keggin archetype on tyrosinase of twin mushrooms. They further clarified the correlation between inhibition and charge-related activity. The results showed that the inhibitory ability of the complete structure of Kegging POTs is proportional to its net charge. Many studies at home and abroad have shown that POMs are expected to become important targets in the treatment of skin pigment diseases, whitening cosmetics and food preservation in the future.

\section{Phosphatase}

Phosphatase is a ubiquitous enzyme in nature, which catalyzes the removal of phosphate groups from various substrates. This dephosphorylation is particularly important for the regulation of the carbohydrate metabolism in metabolic pathways such as glycolysis and gluconeogenesis. Polyoxometalates inhibit a variety of phosphate isozymes, including alkaline phosphatase, acid phosphatase, protein tyrosine phosphatase, glucose- 
Table 1 Inhibition effect of synthetic compounds on tyrosinase ${ }^{41}$

Inhibition constant

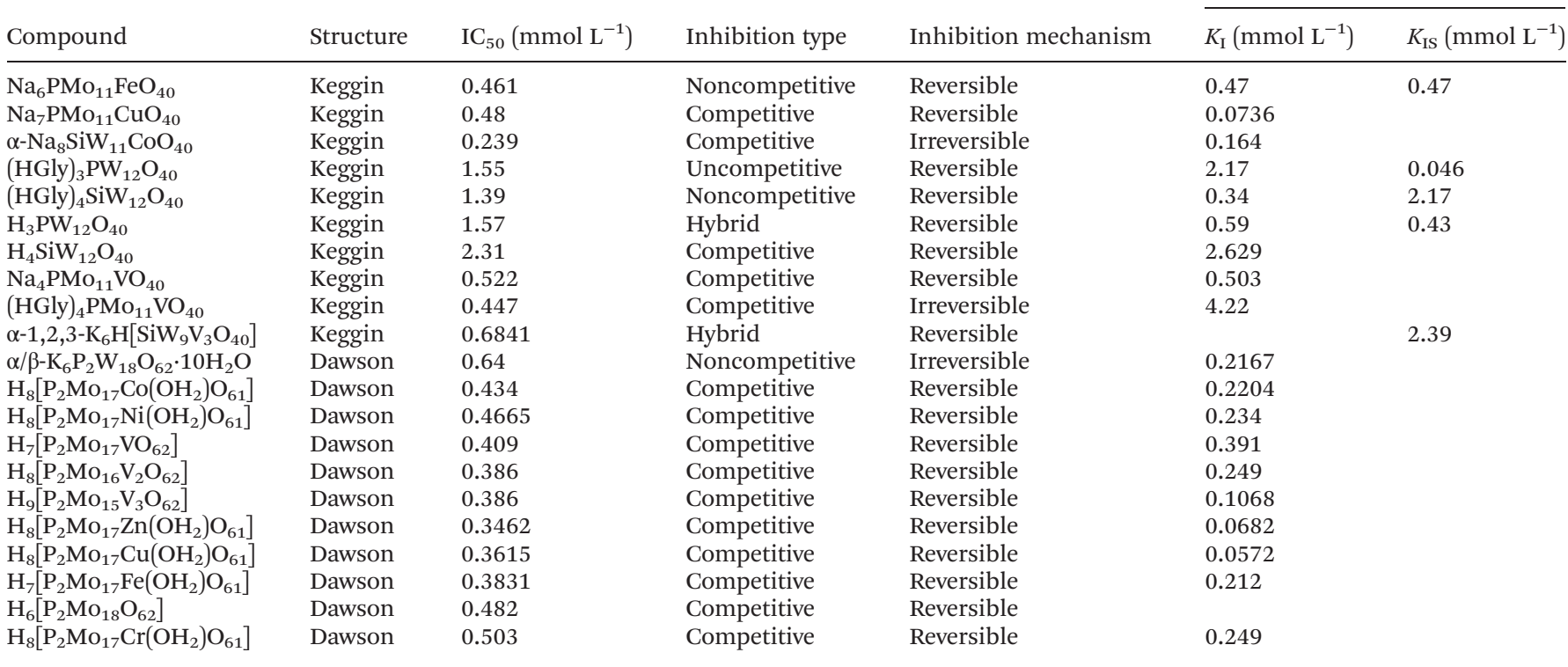

6-phosphatase and phosphoglycerol mutase. ${ }^{12}$ Various studies have shown that vanadium has significant effects on various systems both in vivo and in vitro. The current studies are mainly focused on decavanadate $\mathrm{V}_{10} \mathrm{O}_{28}{ }^{6-}(\mathrm{V} 10) .{ }^{42}$ GomesVieira et $a l^{43}$ analyzed the hyperalkaline phosphotyrosine phosphatase activity (extracellular phosphatase) present on the cell surface of Emerson Bacillus. It showed that in an acidic environment, sodium orthovanadate strongly inhibits the activity of extracellular phosphatase. Leishmaniasis is a serious epidemic with 1.6 million cases reported annually. The secreted acid phosphatase (SAP) of Leishmania has not been paid enough attention as a potential drug target. Dorsey et al. investigated the inhibitory effect of oxovanadium starting material on sap in vitro under the condition of total vanadium, and found that decavanadate is a better SAP inhibitor under the experimental conditions. ${ }^{44}$ Some POMs also showed different degrees of inhibition on phosphatase. ${ }^{45}$ Raza et al. ${ }^{46}$ synthesized seven kinds of polyoxotungstate and studied the inhibitory activity of two main isozymes of alkaline phosphatase. All compounds showed inhibitory activity in the range of nanomole concentration. Among them, $\mathrm{Na}_{10}\left[\mathrm{H}_{2} \mathrm{~W}_{12} \mathrm{O}_{42}\right]$. $27 \mathrm{H}_{2} \mathrm{O}$ had the strongest inhibitory effect on tissue-specific alkaline phosphatase $\left(K_{i}=313 \pm 7 \mathrm{nM}\right)$, and the strongest inhibitory effect on tissue nonspecific alkaline phosphatase $\mathrm{Na}_{33}\left[\mathrm{H}_{7} \mathrm{P}_{8} \mathrm{~W}_{48} \mathrm{O}_{184}\right] \cdot 92 \mathrm{H}_{2} \mathrm{O}(\mathrm{A} 3)\left(K_{i}=135 \pm 10 \mathrm{nM}\right)$. Chitosan can be degraded by the human body, and carrier drugs with chitosan help to play a role in a precise and controllable way. Shah et al. ${ }^{47}$ synthesized three different POMs and prepared nano-assembly materials with chitosan (CTS). Two alkaline phosphatase isozymes, tissue-specific calf small intestinal alkaline phosphatase (CIAP) and tissue non-specific alkaline phosphatase (TNAP), were used to detect the compounds. The results showed that compound $\left[\mathrm{TeW}_{6} \mathrm{O}_{24}\right]^{6-}\left(\mathrm{TeW}_{6}\right)$ had the highest anti-TNAP activity $\left(K_{i}=45.4 \pm 11.3 \mathrm{nM}\right)$, chitosan$\left[\mathrm{TeW}_{6} \mathrm{O}_{24}\right]^{6-}\left(\mathrm{CTS}-\mathrm{TeW}_{6}\right)$ had a strong inhibitory effect on CIAP $\left(K_{i}=22 \pm 7 \mathrm{nM}\right)$.

\section{Extracellular nucleotidase}

Extracellular nucleotidase is a glycoprotein bound or secreted by cell membrane, which plays an important role in regulating purine signal by participating in the hydrolysis of extracellular nucleotides. ${ }^{48}$ Extracellular nucleotidase is a membranebinding enzyme family, which mainly includes four different families: extracellular nucleoside triphosphate diphosphate hydrolase (NTPDases), extracellular nucleotide pyrophosphatase/phosphodiesterase (NPPs), alkaline phosphatase (APs) and extracellular 50-nucleotidase (EN). ${ }^{49}$ Inhibition of these enzymes may increase the immune response and help fight cancer, autoimmune diseases, and bacterial and viral infections. ${ }^{47}$ Lee et al. ${ }^{49}$ evaluated the inhibitory effect of a series of polyoxometalates on various extracellular nucleotidases. $\left[\mathrm{Co}_{4}\left(\mathrm{H}_{2} \mathrm{O}\right)_{2}\left(\mathrm{PW}_{9} \mathrm{O}_{34}\right)_{2}\right]^{10-}$ is the most effective inhibitor against human PSB reported so far $\left(K_{i}=3.88 \mathrm{nM}\right)$. POM compounds in other studies selectively inhibit human NPP1, $\left[\mathrm{TiW}_{11} \mathrm{CoO}_{40}\right]^{8-}$ and $\left[\mathrm{NaSb}_{9} \mathrm{~W}_{21} \mathrm{O}_{86}\right]^{18-}$, which are the most effective and selective human NPP1 inhibitors reported so far. $\left[\mathrm{NaP}_{5} \mathrm{~W}_{30} \mathrm{O}_{110}\right]^{14-}$ has a strong inhibitory effect on NTPDase1-3 and NPP1, and can be used as a PAN inhibitor to block the hydrolysis of ATP. Polyoxy anion compounds showed a non-competitive inhibition mechanism on NPPs and EN. Müller et al. ${ }^{50}$ found that polyoxotungstates are an effective inhibitor of NTPDases1, 2 and 3, among which $\mathrm{K}_{6} \mathrm{H}_{2}\left[\mathrm{TiW}_{11} \mathrm{CoO}_{40}\right]$ is the most effective compound with $K_{i}$ values of $0.140 \mu \mathrm{M}$ (NTPDase1), $0.910 \mu \mathrm{M}$ (NTPDase2) and $0.563 \mu \mathrm{M}$ (NTPDase3), respectively. One of the compounds $\left(\mathrm{NH}_{4}\right)_{18}\left[\mathrm{NaSb}_{9} \mathrm{~W}_{21} \mathrm{O}_{86}\right]$ is more selective to NTPDases 2 and 3 than NTPDase1. Inhibition of NTPDase may 
help to describe the biological effects of polyoxometalates, including their anticancer activity. ARL67156 is the best NTPDase inhibitor available at present, but its therapeutic effect is still not satisfactory. Wall et al. ${ }^{51}$ tested the effectiveness and physiological effects of polyoxotungstate $\left(\mathrm{Na}_{6}\left[\mathrm{H}_{2} \mathrm{~W}_{12} \mathrm{O}_{40}\right]\right.$, POM-1) in cerebellum and hippocampal slices and found that POM-1 is a new type of NTPDase inhibitor with good inhibitory effect on recombinant NTPDase1, 2 and 3. Using malachite green phosphate test, high performance liquid chromatography and biosensor measurements, we found that POM-1 was more effective than ARL67156 in preventing the decomposition of adenosine triphosphate in cerebellar slices. The inhibitory effect of POM-1 occurs in the first step of the cascade reaction (the conversion of ATP to ADP), and POM-1 seems to be reversible. The increase of paired pulse ratio and the decrease of presynaptic intercept amplitude suggest that there is a presynaptic component in the action of POM-1, which reduces the release of glutamate. Therefore, although POM-1 is more effective than APL67156 in preventing ATP decomposition, its effectiveness is limited by the nontarget role of synaptic transmission.

\section{Sialic acid/sulfonyltransferase}

The sugar chains on the cell surface are widely modified by sulfonyl and salivary acyltransferases. The enzyme plays an important role in microbial infections and diseases including cancer. Microbes usually use specific sialylated/sulfated polysaccharides on the cell surface as the initial step of infection. Therefore, sialic acid/sulfonyltransferase inhibitors may be drugs for the treatment of such infections and diseases. Seko et $a l .{ }^{52}$ found that polyoxometalates can inhibit the activities of $\beta$-galactoside $\alpha$-2meme 3 -sialyltransferase1(ST3Gal-1) and 3-galactose- $O$-sulfonyltransferase-2(Gal3ST-2). Some polytungstates can inhibit the activity of ST3Gal-1 at sub-nanomole concentrations. A polytungstate with stronger inhibition effect is $\mathrm{K}_{6}\left[\mathrm{H}_{2} \mathrm{SiNiW}_{11} \mathrm{O}_{40}\right] \cdot 13 \mathrm{H}_{2} \mathrm{O}(\mathrm{POM} 6), \mathrm{K}_{12}\left[\mathrm{Cu}_{3}\left(\mathrm{PW}_{9} \mathrm{O}_{34}\right)_{2}\right] \cdot x \mathrm{H}_{2} \mathrm{O}$ (POM13) and $\mathrm{K}_{5}\left[\mathrm{SiVW}_{11} \mathrm{O}_{40}\right] \cdot \mathrm{xH}_{2} \mathrm{O}(\mathrm{POM} 14)$. Its semi-inhibitory concentration $\left(\mathrm{IC}_{50}\right)$ is $0.2 \mathrm{nmol} \mathrm{L} \mathrm{L}^{-1}$, and the inhibition type is non-competitive. $\mathrm{K}_{5}\left[\mathrm{H}_{6} \mathrm{KV}_{13} \mathrm{O}_{31}\left(\mathrm{MePO}_{3}\right)_{3}\right] \cdot 16 \mathrm{H}_{2} \mathrm{O}(\mathrm{POM} 15)$, $\mathrm{K}_{10}\left[\mathrm{H}_{2} \mathrm{~V}_{18} \mathrm{O}_{42}\left(\mathrm{H}_{2} \mathrm{O}\right)\right] \cdot 16 \mathrm{H}_{2} \mathrm{O}(\mathrm{POM} 16)$ and $\mathrm{Na}_{12} \mathrm{H}_{2}\left[\mathrm{H}_{2} \mathrm{~V}_{18} \mathrm{O}_{44}\left(\mathrm{~N}_{3}\right)\right]$. $30 \mathrm{H}_{2} \mathrm{O}$ (POM18) had a strong inhibitory effect on galactose-3 sulfonyltransferase (Gal3ST-2), and the $\mathrm{IC}_{50}$ value was about 3 nM. In addition, other polyvanadates can also inhibit the activity of ST3Gal-1 and Gal3ST-2 at the nanomole concentration. The steady-state kinetic study of $\mathrm{K}_{9} \mathrm{H}_{5}\left[\left(\mathrm{GeTi}_{3} \mathrm{~W}_{9} \mathrm{O}_{37}\right)_{2} \mathrm{O}_{3}\right]$. $16 \mathrm{H}_{2} \mathrm{O}(\mathrm{PM}-504)$ by Yamase et $a l^{53}$ shows that the POMs have a non-competitive inhibitory effect on ST3Gal-1, and $\mathrm{K}_{9} \mathrm{H}_{5}\left[\left(\mathrm{GeTi}_{3} \mathrm{~W}_{9} \mathrm{O}_{37}\right)_{2} \mathrm{O}_{3}\right] \cdot 16 \mathrm{H}_{2} \mathrm{O}$ may interact with multiple binding sites of ST3Gal-1. ST3Gal-1 has minimal $\mathrm{IC}_{50}$ values for $\mathrm{K}_{7}\left[\mathrm{PTi}_{2} \mathrm{~W}_{10} \mathrm{O}_{40}\right] \cdot 6 \mathrm{H}_{2} \mathrm{O}, \mathrm{K}_{5}\left[\mathrm{SiVW}_{11} \mathrm{O}_{40}\right] \cdot n \mathrm{H}_{2} \mathrm{O},\left[\mathrm{Et}_{2} \mathrm{NH}_{2}\right]_{7}\left[\mathrm{PTi}_{2} \mathrm{~W}_{10} \mathrm{O}_{40}\right] \cdot$ $4 \mathrm{H}_{2} \mathrm{O}, \quad\left[\mathrm{Pr}^{\mathrm{i}} \mathrm{NH}_{3}\right]_{6} \mathrm{H}\left[\mathrm{PTi}_{2} \mathrm{~W}_{10} \mathrm{O}_{38}\left(\mathrm{O}_{2}\right)_{2}\right] \cdot \mathrm{H}_{2} \mathrm{O}$ and $\mathrm{K}_{11} \mathrm{H}\left[(\mathrm{VO})_{3^{-}}\right.$ $\left.\left(\mathrm{SbW}_{9} \mathrm{O}_{33}\right)_{2}\right] \cdot 27 \mathrm{H}_{2} \mathrm{O}$, which are $0.4,0.2,0.3,0.6$ and $0.4 \mathrm{~nm}$, respectively. These values are 3 orders of magnitude smaller than those of Gal3ST-2 (40,50, 20, 100 and $60 \mathrm{~nm}$, respectively). On the other hand, spherical polyvanadate inhibited the activities of the two enzymes at the same nanomole concen- tration. The inhibitory effect of POMs on sialic acid/sulfonyltransferase activity in vitro is at least 100 to 1000 times stronger than that of any other known inhibitors. The inhibitory effect of $\mathrm{K}_{9} \mathrm{H}_{5}\left[\left(\mathrm{GeTi}_{3} \mathrm{~W}_{9} \mathrm{O}_{37}\right)_{2} \mathrm{O}_{3}\right] \cdot 16 \mathrm{H}_{2} \mathrm{O}$ on mutant ST3Gal-1 enzyme shows that PM-504 inhibits the adsorption of enveloped RNA virus on host cells because $\mathrm{K}_{9} \mathrm{H}_{5}\left[\left(\mathrm{GeTi}_{3} \mathrm{~W}_{9} \mathrm{O}_{37}\right)_{2} \mathrm{O}_{3}\right] \cdot 16 \mathrm{H}_{2} \mathrm{O}$ has a strong interaction not only with 335Arg residues at the end of ST3Gal-1C, but also with other basic amino acid residues. It can be seen that POMs are new inhibitors of specific sialic acid/sulfonyltransferase.

\section{Histone deacetylase}

Histone deacetylase is composed of 18 gene families, which can be divided into I-IV class according to its homology with homologous genes in Saccharomyces cerevisiae. Class I, II and IV are composed of 11 family members, which are called "classical" histone deacetylase (HDAC). Classical HDAC is a promising target for new anticancer drugs. ${ }^{54}$ Studies have shown that abnormal aggregation and expression changes of histone deacetylase are the causes of tumor suppressor genes leading to malignant tumors. HDAC inhibitors can inhibit the growth of tumor cells and lead to transcriptional changes in genes that regulate the biological process of tumor proliferation. Cyclin dependent kinase inhibitor 1A (CDKN1A,p21). P21 is a wellcharacterized tumor suppressor, which negatively regulates cell cycle by inhibiting the activity of the cyclin/Cdk2 complex and blocks DNA replication by binding to proliferating cell nuclear antigen (PCNA). A large number of studies have shown that the ability of HDACIs to activate the p21 promoter and increase p21 protein level is related to the enhancement of histone $\mathrm{H} 3$ and $\mathrm{H} 4$ acetylation near the gene promoter. Dong et $a .^{11}$ used the cell screening system of the p21 gene promoter to screen five new positive histone deacetylase inhibitors (HDACIs), from the polyoxometalates (POMs) library. Three different types of germanium tungstate (PAC-304, PAC-334 and PAC-320) and one phosphotungstate Dawson type (PAC-128) were used to inhibit tumor growth in several tumor cell lines (A549, SW620, HepG2, MM-231, MGC-803). Among them, the novel ternary organic substituted tin germanium tungstate PAC-320 showed significant extracellular inhibitory activity. PAC-320 has a strong inhibitory effect on intracellular HDAC activity. More significantly, PAC-320 inhibited the growth of many kinds of cancer cells and showed significant anticancer effect in the mouse model of hepatoma H22 cells. PAC-320 is not only a strong HDAC inhibitor, but also has good antitumor activity (IC50 value for HepG2 is $19.2 \mu \mathrm{g} \mathrm{ml}^{-1}$ ) and low cytotoxicity (IC50 value is $42.8 \mu \mathrm{g} \mathrm{ml}^{-1}$ ).

\section{Cholinesterase}

Cholinesterase (ChE) is an important therapeutic target for Alzheimer's disease (AD). Acetylcholinesterase (AChE; E.C.3.1.1.7) is a key inactivating agent of acetylcholine(Ach) released by neurons, but butyrylcholinesterase (BuChE; E.C.3.1.1.8) can also cleave ACh, mainly from glial cells, which plays an important role in the pathological process of $\mathrm{AD}$. Currently, the drugs that can be used for AD are mainly cholin- 
esterase inhibitors. ${ }^{55}$ However, the therapeutic effect of these clinical inhibitors is not satisfactory, and only has a certain effect on mild to moderate Alzheimer's disease, so scientists began to look for alternatives of cholinesterase inhibitors with better efficacy and less toxicity. Long-term cell culture analysis, in vitro enzyme activity and molecular model studies of POMs show that POMs have good biological activity against Alzheimer's disease. ${ }^{56}$ Iqbal et al. ${ }^{57}$ found that some polyoxotungstates can be used as effective inhibitors of acetylcholinesterase and butyrylcholinesterase, among which compounds
$\left[\mathrm{H}_{2} \mathrm{~W}_{12} \mathrm{O}_{42}\right]^{10-}$ and $\left[\mathrm{TeW}_{6} \mathrm{O}_{24}\right]^{6-}$ have the best inhibitory effect on acetylcholinesterase activity, showing $\mathrm{IC}_{50}$ values of $0.29 \pm$ $0.01 \mu \mathrm{mol} \mathrm{L}{ }^{-1}$ and $0.31 \pm 0.01 \mu \mathrm{mol} \mathrm{L^{-1 }}$ respectively, while compound $\left[\left(\mathrm{O}_{3} \mathrm{PCH}_{2} \mathrm{PO}_{3}\right)_{4} \mathrm{~W}_{12} \mathrm{O}_{36}\right]^{16-}$ is an effective selective inhibitor of butyrylcholinesterase. Its $\mathrm{IC}_{50}$ value is $0.18 \pm$ $0.05 \mu \mathrm{mol} \mathrm{L}{ }^{-1}$. Čolović et al. ${ }^{58}$ evaluated the toxicity of two Keggin heteropoly salts $\mathrm{K}_{7}\left[\mathrm{Ti}_{2} \mathrm{PW}_{10} \mathrm{O}_{40}\right] \cdot 6 \mathrm{H}_{2} \mathrm{O}$ and $\mathrm{K}_{6} \mathrm{H}$ $\left[\mathrm{SiV}_{3} \mathrm{~W}_{9} \mathrm{O}_{40}\right] \cdot 3 \mathrm{H}_{2} \mathrm{O}$ with different inhibitory effects on acetylcholinesterase activity $\left(\mathrm{IC}_{50}=1.04 \times 10^{-6}\right.$ and $4.80 \times 10^{-4} \mathrm{~mol}$ $\mathrm{L}^{-1}$, respectively). The results showed that the toxicity of the

Table 2 Inhibition of synthetic compounds on different enzymes

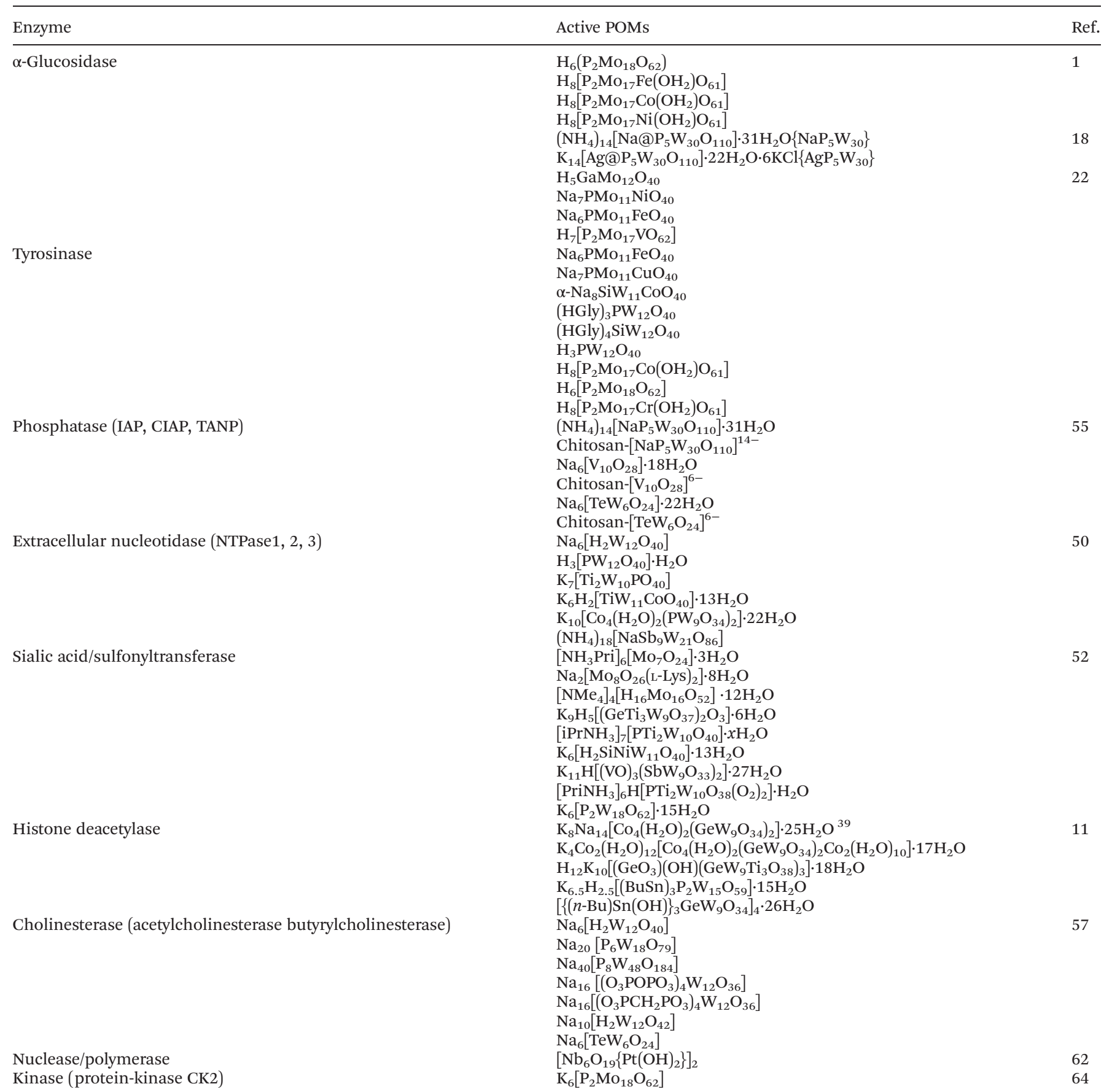


two polyoxotungstate with anti-acetylcholinesterase activity was mild. In the latest research, Bondžić ${ }^{59}$ discovered a new acetylcholinesterase allosteric site responsible for binding voluminous negatively charged molecules, which are called the $\beta$-allosteric site $(\beta$-AS). It has been shown that two inhibitors, 12-tungstosilicic acid (WSiA) and 12-tungstophosphoric acid (WPA) with a polyoxometalate (POM) type structure, can inhibit AChE activity at $\mathrm{nM}$ concentration. These studies make it possible to design and screen more POM compounds as drugs for the treatment of Alzheimer's disease.

\section{Nuclease/polymerase}

Nuclease can hydrolyze polynucleotides (RNA, DNA), while polymerase can catalyze the synthesis of polynucleotides. In vitro experiments, it has been found that POMs can inhibit not only nuclease but also nucleic acid polymerase, especially the inhibitory effect of POMs on human immunodeficiency virus reverse transcriptase (HIV-RT), which has been widely studied. ${ }^{60}$ HIV-RT is a typical RNA-dependent viral DNA polymerase. Many POMs show good potency at micromoles or even lower concentrations. However, Inouye et al. ${ }^{61}$ did not find the correlation between HIV-RT and anti-HIV activity, which may be due to the fact that POMS is not easy to reach intracellular targets such as DNA polymerase. Therefore, the antiviral effect of POMS is likely to be a different mechanism. In addition, other POMs have an effect on the activity of DNA polymerase, but are not inhibitors of DNA polymerase. For example, Yudkina et $a l^{62}$ found that platinum polyoxoniobate $\left(\left[\mathrm{Nb}_{6} \mathrm{O}_{19}\left\{\mathrm{Pt}(\mathrm{OH})_{2}\right\}\right]_{2}\right)$ did not act as an inhibitor of DNA polymerases, but can form adducts with DNA.

\section{Kinase}

Different kinases, including hexokinase, phosphofructokinase and protein kinase $\mathrm{CK} 2$, have been found to be inhibited by a variety of polyoxometalates. Donald et $a l .{ }^{63}$ found that trimer and tetramer vanadate could not affect kinase activity in all cases. However, perovanadate prepared under the condition of pH 4 could inhibit hexokinase and fructose phosphokinase, and seemed to be non-competitive inhibitors of two hexokinase substrates. Renaud et al. verified the inhibitory effect of POMs on protein kinase CK2 with a large amount of data, in which $\quad \mathrm{K}_{6}\left[\mathrm{P}_{2} \mathrm{Mo}_{18} \mathrm{O}_{62}\right], \quad \mathrm{Na}_{17}\left[\left(\mathrm{P}_{2} \mathrm{~W}_{15} \mathrm{O}_{56}\right)_{2} \mathrm{Co}_{4}\left(\mathrm{H}_{2} \mathrm{O}\right)(\mathrm{OH})\right]$, $\mathrm{K}_{28} \mathrm{Li}_{5} \mathrm{H}_{7}\left[\mathrm{P}_{8} \mathrm{~W}_{48} \mathrm{O}_{184}\right] \cdot 92 \mathrm{H}_{2} \mathrm{O}$ had a better inhibitory effect, reducing the residual activity of $70 \mathrm{nM}$ protein kinase CK2 to $<5 \%, 7 \%, 0.3 \%$ and $8 \%$, respectively. The specific spectral analysis of $\left[\mathrm{P}_{2} \mathrm{Mo}_{18} \mathrm{O}_{62}\right]^{6-}$ showed that the POM could inhibit not only protein kinase $\mathrm{CK} 2$, but also 28 kinases such as Ab1, Bmx, c-RAF. $\left[\mathrm{P}_{2} \mathrm{Mo}_{18} \mathrm{O}_{62}\right]^{6-}$ has strong activity. It inhibits kinases in the nanomole range by targeting key structural elements outside the ATP and peptide binding sites. Polyoxometalate derivatives have a strong inhibitory effect, and the $\mathrm{IC}_{50}$ value is $10 \mathrm{~nm}$. Therefore, polyoxometalates are effective CK2 inhibitors with high efficiency and selectivity, and represent non-classical kinase inhibitors that interact with CK2 in a unique way. Protein kinase CK2 is an unfavorable forward marker in several cancers, so it has become a related therapeutic target. Renaud et al. have identified that polyoxometalates can be used as primitive CK2 inhibitors for key structural elements located outside the active site. Because the interface of the CK2 subunit represents an exosome different from the catalytic cavity, it can be targeted by peptides or small molecules to achieve a functional effect. ${ }^{64}$

\section{Summary and prospect}

Polyoxometalates are very unique compounds, and almost any other element can be incorporated into the frame structure of POMs. Therefore, the great diversity of the structure and properties of polyoxometalates makes them a widely used material in catalytic chemistry, materials science, equipment and biomedical fields. In particular, the application in the biomedical field has aroused great interest among scientists, because compared with the common organic drugs at present, POMs have great potential as inorganic drugs, especially POMs containing transition metals tungsten, molybdenum and vanadium show good biological activities in vivo and in vitro, including anticancer, antibacterial, antiviral, anti-diabetes and so on. These biological activities are more or less related to the inhibition of POMs on enzymes, and various POMs have also been found to have good enzyme inhibitory effect (Table 2). However, some polyoxometalates and their derivatives also show good anticancer and anti-viral properties by inducing apoptosis and inhibit ATP production. For example, She et al. ${ }^{65}$ used a cleavable organic imino to modify hexamolybdic acid to obtain a degradable derivative. The derivative showed good pharmacodynamic effects on human malignant glioma cells, and the degradability of the derivative reduced cytotoxicity. Gu et al. ${ }^{66}$ synthesized two novel polyoxyvanadate-iododiborate supramolecular assemblies, named (2I-BDP- $\left.\mathrm{C}_{6}\right)_{2} \mathrm{~V}_{6}$ and $\left(2 \mathrm{I}-\mathrm{BDP}-\mathrm{C}_{6}\right)_{3} \mathrm{~V}_{10}$. Compared with decavanadate, $\left(2 \mathrm{I}-\mathrm{BDP}-\mathrm{C}_{6}\right){ }_{3} \mathrm{~V}_{10}$ has a higher lethality to lung cancer cells (HepG2). The study of its mode of action will require interdisciplinary cooperation from experts from different backgrounds, such as chemists, pharmacists, crystallographers, physicists, biochemists and doctors. The future research direction is mainly focused on the modification of POMs to enhance their biological targeting and improve the recognition process of POMs to target biomolecules, so as to develop new compounds with better chemical stability and metabolic stability.

\section{Conflicts of interest}

All authors declare that they have no conflict of interest in this work.

\section{Acknowledgements}

This work was supported by the National Natural Science Foundation of China (Grant No. 21871110) and Natural Science Foundation of Fujian Province (Grant No. 2020J01674). 


\section{References}

1 J. J. Hu, L. Wang, B. N. Chen, G. X. Chi, M. J. Zhao and Y. Li, Transition Metal Substituted Polyoxometalates as

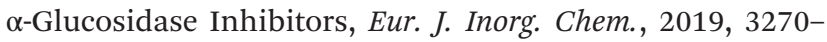
3276, DOI: 10.1002/ejic.201900306.

2 A. Blazevic and A. Rompel, The Anderson-Evans polyoxometalate: From inorganic building blocks via hybrid organic-inorganic structures to tomorrows "Bio-POM.", Coord. Chem. Rev., 2016, 307, 42-64, DOI: 10.1016/j. ccr.2015.07.001.

3 S. J. Li, Y. F. Zhou, Q. B. Peng, R. Y. Wang, X. G. Feng, S. X. Liu, X. M. Ma, N. N. Ma, J. Zhang, Y. Chang, Z. P. Zheng and X. N. Chen, Controllable Synthesis and Catalytic Performance of Nanocrystals of Rare-EarthPolyoxometalates, Inorg. Chem., 2018, 57(11), 6624-6631, DOI: 10.1021 /acs.inorgchem.8b00763.

4 S. G. Tang, Z. Liu, F. P. Ma, G. L. Cao, J. K. Wang, W. Chen, X. J. Feng and Y. F. Zhu, Catalytic activity of porous carbon nitride regulated by polyoxometalates under visible light, RSC Adv., 2020, 10(14), 8255-8260, DOI: 10.1039/ c9ra10441k.

5 D. Li, H. Y. Han, Y. H. Wang, X. Wang, Y. G. Li and E. B. Wang, Modification of Tetranuclear ZirconiumSubstituted Polyoxometalates - Syntheses, Structures, and Peroxidase-Like Catalytic Activities, Eur. J. Inorg. Chem., 2013, 2013(10-11), 1926-1934, DOI: 10.1002/ ejic. 201200791.

6 S. Omwoma, C. T. Gore, Y. C. Ji, C. W. Hu and Y. F. Song, Environmentally benign polyoxometalate materials, Coord. Chem. Rev., 2015, 286, 17-29, DOI: 10.1016/j. ccr.2014.11.013.

7 H. F. Shi, Y. C. Yu, Y. Zhang, X. J. Feng, X. Y. Zhao, H. Q. Tan, S. U. Khan, Y. G. Li and E. B. Wang, Polyoxometalate/TiO2/Ag composite nanofibers with enhanced photocatalytic performance under visible light, Appl. Catal., B, 2018, 221, 280-289, DOI: 10.1016/j. apcatb.2017.09.027.

8 A. Bijelic, M. Aureliano and A. Rompel, The antibacterial activity of polyoxometalates: structures, antibiotic effects and future perspectives, Chem. Commun., 2018, 54(10), 1153-1169, DOI: 10.1039/c7cc07549a.

9 A. Bijelic, M. Aureliano and A. Rompel, Polyoxometalates as potential next-generation metallodrugs in the combat against cancer, Angew. Chem., Int. Ed., 2019, 58(10), 29802999, DOI: 10.1002/anie.201803868.

10 S. Y. Wang, W. J. Sun, Q. Hu, H. Yan and Y. Zeng, Synthesis and evaluation of pyridinium polyoxometalates as antiHIV-1 agents, Bioorg. Med. Chem. Lett., 2017, 27(11), 23572359, DOI: 10.1016/j.bmcl.2017.04.025.

11 Z. X. Dong, R. K. Tan, J. Cao, Y. Yang, C. F. Kong, J. Du, S. Zhu, Y. Zhang, J. Lu, B. Q. Huang and S. X. Liu, Discovery of polyoxometalate-based HDAC inhibitors with profound anticancer activity in vitro and in vivo, Eur. J. Med. Chem., 2011, 46(6), 2477-2484, DOI: 10.1016/j. ejmech.2011.03.036.
12 H. Stephan, M. Kubeil, F. Emmerling and C. E. Müller, Polyoxometalates as Versatile Enzyme Inhibitors, Eur. J. Inorg. Chem., 2013, 2013(10-11), 1585-1594, DOI: 10.1002/ejic.201201224.

13 R. Xing, A. P. Zheng, F. Wang, L. Wang, Y. P. Yu and A. H. Jiang, Functionality study of Na6PMo11FeO40 as a mushroom tyrosinase inhibitor, Food Chem., 2015, 175, 292-299, DOI: 10.1016/j.foodchem.2014.11.157.

14 R. Xing, F. Wang, L. Dong, A. P. Zheng, L. Wang, W. J. Su and $\mathrm{T}$. Lin, Inhibitory effects of $\mathrm{Na}_{7} \mathrm{PMo}_{11} \mathrm{CuO}_{40}$ on mushroom tyrosinase and melanin formation and its antimicrobial activities, Food Chem., 2016, 197, 205-211, DOI: 10.1016/j.foodchem.2015.10.119.

15 A. Bijelic and A. Rompel, Polyoxometalates: more than a phasing tool in protein crystallography, ChemTexts, 2018, 4(3), DOI: 10.1007/s40828-018-0064-1.

16 J. Breibeck, A. Bijelic and A. Rompel, Transition metal-substituted Keggin polyoxotungstates enabling covalent attachment to proteinase $\mathrm{K}$ upon co-crystallization, Chem. Commun., 2019, 55(77), 11519-11522, DOI: 10.1039/ c9cc05818d.

17 S. Iqbal, N. U. Rehman, U. Kortz and J. Iqbal, Development of a fast and efficient CE enzyme assay for the characterization and inhibition studies of $\alpha$-glucosidase inhibitors, J. Sep. Sci., 2013, 36(21-22), 3623-3628, DOI: 10.1002/ jssc. 201300758.

18 M. Dinčić, M. B. Čolović, M. S. Matutinović, M. Ćetković, T. K. Stevović, A. S. Mougharbel, J. Todorović, S. Ignjatović, B. Radosavljević, M. Milisavljević, U. Kortz and D. Z. Krstić, In vivo toxicity evaluation of two polyoxotungstates with potential antidiabetic activity using Wistar rats as a model system, RSC Adv., 2020, 10(5), 2846-2855, DOI: 10.1039/ C9RA09790B.

19 N. Nanayakkara, S. Ranasinha, A. Gadowski, S. Heritier, J. R. Flack, N. Wischer, J. Wong and S. Zoungas, Age, age at diagnosis and diabetes duration are all associated with vascular complications in type 2 diabetes, $J$. Diabetes Complicat., 2018, 32(3), 279-290, DOI: 10.1016/j. jdiacomp.2017.11.009.

20 J. H. Beynon, A. E. Fontaine and B. E. Job, Synthesis and Biological Activity of Novel Deoxynojirimycin Derivatives as Potent $\alpha$-Glucosidase Inhibitors, Z. Naturforsch., B: J. Chem. Sci., 2013, 68(4), 383-390, DOI: 10.5560/ZNB.2013-2318.

21 Z. Ilyas, H. S. Shah, R. Al-Oweini, U. Kortz and J. Iqbal, Antidiabetic potential of polyoxotungstates in vitro and in vivo studies, Metallomics, 2014, 6(8), 1521-1526, DOI: 10.1039/C4MT00106K.

22 G. X. Chi, L. Wang, B. N. Chen, J. Li, J. J. Hu, S. X. Liu, M. J. Zhao, X. M. Ding and Y. Li, Polyoxometalates: Study of inhibitory kinetics and mechanism against $\alpha$-glucosidase, J. Inorg. Biochem., 2019, 199, 110784, DOI: 10.1016/j. jinorgbio.2019.110784.

23 G. X. Chi, Y. F. Qi, J. Li, L. Wang and J. J. Hu, Polyoxomolybdates as $\alpha$-glucosidase inhibitors Kinetic and molecular modeling studies, J. Inorg. Biochem., 2019, 193, 173-179, DOI: 10.1016/j.jinorgbio.2019.02.001. 
24 J. J. Hu, L. Wang, F. Wang, G. X. Chi, G. M. Liu and L. C. Sun, Molecular docking of polyoxometalates as potential $\alpha$-glucosidase inhibitors, J. Inorg. Biochem., 2020, 203, 110914, DOI: 10.1016/j.jinorgbio.2019.110914.

25 Y. Y. Liu, Q. Yang, G. P. Xia, H. B. Huang, H. X. Li, L. Ma, Y. J. Lu, L. He, X. K. Xia and Z. G. She, Polyketides with $\alpha$-Glucosidase Inhibitory Activity from a Mangrove Endophytic Fungus, Penicillium sp. HN29-3B1, J. Nat. Prod., 2015, 78(8), 1816-1822, DOI: 10.1021/np500885f.

26 A. Korner and J. Pawelek, Mammalian tyrosinase catalyzes three reactions in the biosynthesis of melanin, Science, 1982, 217 (4565), 1163-1165, DOI: 10.1126/science.6810464.

27 T. Pillaiyar, M. Manickam and S. H. Jung, Recent development of signaling pathways inhibitors of melanogenesis, Cell. Signal., 2017, 40, 99-115, DOI: 10.1016/j. cellsig.2017.09.004.

28 W. Yi, C. Dubois, S. Yahiaoui, R. Haudecoeur, C. Belle, H. C. Song, R. Hardré, M. Réglier and A. Boumendjel, Refinement of arylthiosemicarbazone pharmacophore in inhibition of mushroom tyrosinase, Eur. J. Med. Chem., 2011, 46(9), 4330-4335, DOI: 10.1016/j.ejmech.2011.07.003.

29 R. Quevedo, F. Pedreschi, J. M. Bastias and O. Díaz, Correlation of the fractal enzymatic browning rate with the temperature in mushroom, pear and apple slices, $L W T$, 2016, 65, 406-413, DOI: 10.1016/j.lwt.2015.08.052.

30 Z. J. Sheng, S. Y. Ge, X. M. Xu, Y. Zhang, P. P. Wu, K. Zhang, X. T. Xu, C. Li, D. G. Zhao and X. W. Tang, Design, synthesis and evaluation of cinnamic acid ester derivatives as mushroom tyrosinase inhibitors, MedChemComm, 2018, 9(5), 853-861, DOI: 10.1039/ c8md00099a.

31 T. Oyama, S. Takahashi, A. Yoshimori, T. Yamamoto, A. Sato, T. Kamiya, H. Abe, T. Abe and S. Tanuma, Discovery of a new type of scaffold for the creation of novel tyrosinase inhibitors, Bioorg. Med. Chem. Lett., 2016, 24(18), 4509-4515, DOI: 10.1016/j.bmc.2016.07.060.

32 H. J. Si, X. Wang, L. P. Li, M. M. Song and R. M. Gong, Inhibitory effects of 4-chlorocinnamaldehyde on the activity of mushroom tyrosinase, Med. Chem. Res., 2017, 26(7), 1377-1381, DOI: 10.1007/s00044-017-1861-6.

33 T. Pillaiyar, M. Manickam and V. Namasivayam, Skin whitening agents: medicinal chemistry perspective of tyrosinase inhibitors, J. Enzyme Inhib. Med. Chem., 2017, 32(1), 403-425, DOI: 10.1080/14756366.2016.1256882.

34 S. Kim, H. Seo, H. A. Mahmud, M. I. Islam, O. F. Sultana, Y. Lee, M. Kim and H. Y. Song, Melanin Bleaching and Melanogenesis Inhibition Effects of Pediococcus acidilactici PMC48 Isolated from Korean Perilla Leaf Kimchi, J. Microbiol. Biotechnol., 2020, 30(7), 1051-1059, DOI: 10.4014/jmb.2003.03007.

35 A. Rescigno, F. Sollai, B. Pisu, A. Rinaldi and E. Sanjust, Tyrosinase Inhibition General and Applied Aspects, J. Enzyme Inhib. Med. Chem., 2002, 17(4), 207-218, DOI: 10.1080/14756360210000010923.

36 G. X. Chi, L. F. Xie, M. J. Zhao, L. Wang, F. Wang, J. Li and A. P. Zheng, Biological Evaluation of Keggin-type
Polyoxometalates on Tyrosinase: Kinetics and Molecular Modeling, Chem. Biol. Drug Des., 2020, DOI: 10.1111/ cbdd.13734.

37 B. N. Chen, R. Xing, F. Wang, A. P. Zheng and L. Wang, Inhibitory effects of $\alpha-\mathrm{Na}_{8} \mathrm{SiW}_{11} \mathrm{CoO}_{40}$ on tyrosinase and its application in controlling browning of fresh-cut apples, Food Chem., 2015, 188, 177-183, DOI: 10.1016/j. foodchem.2015.05.003.

38 R. Xing, F. Wang, A. P. Zheng, L. Wang, D. Fei and Y. P. Yu, Biological evaluation of two Keggin-type polyoxometalates containing glycine as mushroom tyrosinase inhibitors, Biotechnol. Appl. Biochem., 2015, 63(5), 746-750, DOI: 10.1002/bab.1424.

39 X. Y. Hu, B. N. Chen, L. Wang and F. H. Chen, Inhibition of $\alpha / \beta-\mathrm{K}_{6} \mathrm{P}_{2} \mathrm{~W}_{18} \mathrm{O}_{62} \cdot 10 \mathrm{H}_{2} \mathrm{O}$ on the activity of mushroom tyrosinase and its antimicrobial effects, Chem. Res. Chin. Univ., 2012, 28(5), 862-865http://apps.webofknowledge.com/full_ record.do?product=UA\&search_mode=GeneralSearch\&qid= $10 \&$ SID $=8$ ECLqbAYrFLPfclB2Pt\&page $=2 \&$ doc $=18$.

40 J. Breibeck, N. I. Gumerova, B. B. Boesen, M. Galanski and A. Rompel, Keggin-type polyoxotungstates as mushroom tyrosinase inhibitors - A speciation study, Sci. Rep., 2019, 9(1), DOI: 10.1038/s41598-019-41261-7.

41 M. J. Zhao, J. J. Hu, H. Ni, Z. D. Jiang and L. Wang, Research progress in melanogenesis signaling pathway, Chin. J. Biotechnol., 2019, 35(9), 1633-1642, DOI: 10.13345/ j.cjb.190084, (in Chinese).

42 T. L. Turner, V. H. Nguyen, C. C. McLauchlan, Z. Dymon, B. M. Dorsey, J. D. Hooker and M. A. Jones, Inhibitory effects of decavanadate on several enzymes and Leishmania tarentolae in vitro, J. Inorg. Biochem., 2012, 108, 96-104, DOI: 10.1016/j.jinorgbio.2011.09.009.

43 A. L. Gomes-Vieira, L. Paes-Vieira, D. K. B. B. Zamboni, A. L. A. Dos-Santos, C. F. Dick and J. R. Meyer-Fernandes, Ectophosphatase activity in the early-diverging fungus Blastocladiella emersonii: Biochemical characterization and possible role on cell differentiation, Fungal Genet. Biol., 2018, 117, 43-53, DOI: 10.1016/j.fgb.2018.07.005.

44 B. M. Dorsey, C. C. McLauchlan and M. A. Jones, Evidence That Speciation of Oxovanadium Complexes Does Not Solely Account for Inhibition of Leishmania Acid Phosphatases, Front. Chem., 2018, 6, 109, DOI: 10.3389/ fchem.2018.00109.

45 S. Y. Lee, A. Fiene, W. J. Li, T. Hanck, K. A. Brylev, V. E. Fedorov, J. Lecka, A. Haider, H. J. Pietzsch and H. Zimmermann, Polyoxometalates-Potent and selective ecto-nucleotidase inhibitors, Biochem. Pharmacol., 2015, 93(2), 171-181, DOI: 10.1016/j.bcp.2014.11.002.

46 R. Raza, A. Matin, S. Sarwar, M. Barsukova-Stuckart, M. Ibrahim, U. Kortz and J. Iqbal, Polyoxometalates as potent and selective inhibitors of alkaline phosphatases with profound anticancer and amoebicidal activities, Dalton Trans., 2012, 41(47), 14329-14336, DOI: 10.1039/ c2dt31784b.

47 H. S. Shah, R. Al-Oweini, A. Haider, U. Kortz and J. Iqbal, Cytotoxicity and enzyme inhibition studies of polyoxometa- 
lates and their chitosan nanoassemblies, Toxicol. Rep., 2014, 1, 341-352, DOI: 10.1016/j.toxrep.2014.06.001.

48 H. Zimmermann, M. Zebisch and N. Sträter, Cellular function and molecular structure of ecto-nucleotidases, Purinergic Signalling, 2012, 8(3), 437-502, DOI: 10.1007/ s11302-012-9309-4.

49 S. Y. Lee, A. Fiene, W. J. Li, T. Hanck, K. A. Brylev, V. E. Fedorov, J. Lecka, A. Haider, H. J. Pietzsch, H. Zimmermann, J. Sévigny, U. Kortz, H. Stephan and C. E. Müller, Polyoxometalates-Potent and selective ectonucleotidase inhibitors, Biochem. Pharmacol., 2015, 93(2), 171-181, DOI: 10.1016/j.bcp.2014.11.002.

50 C. E. Müller, J. Iqbal, Y. Baqi, H. Zimmermann, A. Röllich and H. Stephan, Polyoxometalates-a new class of potent ecto-nucleoside triphosphate diphosphohydrolase (NTPDase) inhibitors, Bioorg. Med. Chem. Lett., 2006, 16(23), 5943-5947, DOI: 10.1016/j.bmcl.2006.09.003.

51 M. J. Wall, G. Wigmore, J. Lopatář, B. G. Frenguelli and N. Dale, The novel NTPDase inhibitor sodium polyoxotungstate (POM-1) inhibits ATP breakdown but also blocks central synaptic transmission, an action independent of NTPDase inhibition, Neuropharmacology, 2008, 55(7), 1251-1258, DOI: 10.1016/j.neuropharm.2008. 08.005 .

52 A. Seko, T. Yamase and K. Yamashita, Polyoxometalates as effective inhibitors for sialyl- and sulfotransferases, J. Inorg. Biochem., 2009, 103(7), 1061-1066, DOI: 10.1016/j. jinorgbio.2009.05.002.

53 T. Yamase, Polyoxometalates active against tumors, viruses, and bacteria, Prog. Mol. Subcell. Biol., 2013, 54, 65-116, DOI: 10.1007/978-3-642-41004-8_4.

54 Aİ UBA and K. YelekÇI, Exploration of the binding pocket of histone deacetylases: the design of potent and isoformselective inhibitors, Turk. J. Biol., 2017, 41(6), 901-918, DOI: 10.3906/biy-1701-26.

55 K. Sharma, Cholinesterase inhibitors as Alzheimer's therapeutics, Mol. Med. Rep., 2019, 20(2), 1479-1487, DOI: 10.3892/mmr.2019.10374.

56 J. Geng, M. Li, J. S. Ren, E. B. Wang and X. G. Qu, Polyoxometalates as Inhibitors of the Aggregation of Amyloid $\beta$ Peptides Associated with Alzheimer's Disease, Angew. Chem., Int. Ed., 2011, 50(18), 4184-4188, DOI: 10.1002/anie.201007067.

57 J. Iqbal, M. Barsukova-Stuckart, M. Ibrahim, S. U. Ali, A. A. Khan and U. Kortz, Polyoxometalates as potent inhibitors for acetyl and butyrylcholinesterases and as potential drugs for the treatment of Alzheimer's disease, Med. Chem.
Res., 2014, 22(3), 1224-1228, DOI: 10.1007/s00044-0120125-8.

58 M. B. Čolović, B. Medić, M. Ćetković, S. T. Kravić, M. Stojanović, W. W. Ayass, A. S. Mougharbel, M. Radenković, M. Prostran, U. Kortz and D. Z. Krstić, Toxicity evaluation of two polyoxotungstates with antiacetylcholinesterase activity, Toxicol. Appl. Pharmacol., 2017, 333, 68-75, DOI: 10.1016/j.taap.2017.08.010.

59 A. M. Bondžić, T. D. Lazarević-Pašti, A. R. Leskovac, SŽ Petrović, M. B. Čolović, T. N. Parac-Vogt and G. V. Janj, A new acetylcholinesterase allosteric site responsible for binding voluminous negatively charged molecules - the role in the mechanism of AChE inhibition, Eur. J. Pharm. Sci., 2020, 151, 105376, DOI: 10.1016/j.ejps.2020.105376.

60 S. Y. Wang, W. J. Sun, Q. Hu, H. Yan and Y. Zeng, Synthesis and evaluation of pyridinium polyoxometalates as antiHIV-1 agents, Bioorg. Med. Chem. Lett., 2017, 27(11), 23572359, DOI: 10.1016/j.bmcl.2017.04.025.

61 Y. Inouye, Y. Tokutake, J. Kunihara, T. Yoshida, T. Yamase, A. Nakata and S. Nakamura, Suppressive Effect of Polyoxometalates on the Cytopathogenicity of Human Immunodeficiency Virus Type 1 (HIV-1) in Vitro and Their Inhibitory Activity against HIV-1 Reverse Transcriptase, Chem. Pharm. Bull., 1992, 40(3), 805-807, DOI: 10.1248/ cpb.40.805.

62 A. V. Yudkinaa, M. N. Sokolov, P. A. Abramov, R. Grina and D. O. Zharkova, Platinum Polyoxoniobates Form Adducts with DNA, Russ. J. Org. Chem., 2019, 45(6), 641-646, DOI: 10.1134/S1068162019060414.

63 W. B. Donald, K. Kenneth and N. Maho, Do vanadate polyanions inhibit phosphotransferase enzymes, Biochim. Biophys. Acta, Protein Struct. Mol. Enzymol., 1985, 827(3), 472-475, DOI: 10.1016/0167-4838(85)90235-3.

64 P. Renaud, C. F. Sautel and C. Claude, Structure-based discovery of small molecules targeting different surfaces of protein-kinase CK2, Biochim. Biophys. Acta, Biomembr., 2010, 1804, 493-498, DOI: 10.1016/j.bbapap.2009.09.003.

65 S. She, S. T. Bian, R. C. Huo, K. Chen, Z. H. Huang, J. W. Zhang, J. Hao and Y. G. Wei, Degradable OrganicallyDerivatized Polyoxometalate with Enhanced Activity against Glioblastoma Cell Line, Sci. Rep., 2016, 6(1), 33529, DOI: 10.1038/srep33529.

66 Y. Q. Gu, Q. Li, Y. C. Huang, Y. T. Zhu, Y. G. Wei and L. Ruhlmann, Polyoxovanadate-IodoBodipy Supramolecular Assemblies: New Agents for High Efficiency Cancer Photochemotherapy, Chem. Commun., 2020, 56(19), DOI: 10.1039/C9CC09944A. 